\title{
Germination and Viability of Seeds of Caesalpinia pulcherrima Newly Harvested and Stored
}

\author{
Janaina S. Ferro ${ }^{1}$, Dougllas F. Rocha ${ }^{1}$, João Luciano A. M. Junior ${ }^{2}$, João C. A. Neto ${ }^{2}$, José V. Silva $^{1}$ \\ \& Jessé M. S. Junior Pavão ${ }^{1,3}$ \\ ${ }^{1}$ Laboratory of Plant Physiology, Federal University of Alagoas, Arapiraca, Alagoas, Brazil \\ ${ }^{2}$ Laboratory of Plant Propagation, Agricultural Science Center, Federal University of Alagoas, Rio Largo, \\ Alagoas, Brazil \\ ${ }^{3}$ Postgraduate Program in Environmental Systems Analysis, University Center Cesmac, Maceió, Alagoas, Brazil \\ Correspondence: Jessé Marques da Silva Junior Pavão, Laboratory of Plant Physiology, Federal University of \\ Alagoas, Avenue Manoel Severino Barbosa, Bom Sucesso, Arapiraca, Alagoas, Zip Code: 57309-005, Brazil. Tel: \\ 55-829-9674-1218. E-mail: jesse.marques@cesmac.edu.br
}

$\begin{array}{ll}\text { Received: October 15, } 2018 & \text { Accepted: March 28, } 2019 \quad \text { Online Published: May 31, } 2019 \\ \text { doi:10.5539/jas.v11n7p73 } & \text { URL: https://doi.org/10.5539/jas.v11n7p73 }\end{array}$

\begin{abstract}
Caesalpinia pulcherrima is an exotic shrub species, belonging to the Fabaceae family, that has medicinal properties, and is widely used for urban afforestation. The objective of this research was to evaluate the overcoming of the $C$. pulcherrima seed dormancy, the influence of temperature, storage, and water quantity on the substrate in the germination of the species, as well as the use of the tetrazolium test for viability analysis. The analyzes were carried out at the Plant Propagation Laboratory at the Agricultural Sciences Center of the Federal University of Alagoas, in the municipality of Rio Largo, Brazil, and at the Laboratory of Plant Physiology, Arapiraca Campus, at the same University. The experiments were performed under a completely randomized design, with four replicates of 25 seeds. The results demonstrated that during storage the seeds developed a possible secondary dormancy, which was overcome with a time of twelve months of storage. The C. pulcherrima seeds subjected to the test of light qualities presented a significant difference in their germination percentage when verified with the time of storage. In the far-red quality, the newly harvested seeds had a germination percentage of $(98 \%)$, higher than seeds with 12 months of storage $(80.5 \%)$. The water volume 3.5 -fold the weight of the dry paper provides $(90 \%)$ germination when compared to other volumes. The tetrazolium salt concentrations of $0.075 \%$ and $0.1 \%$, under the temperature of $30^{\circ} \mathrm{C}$ within 2 hours, are indicated for the viability analysis of Caesalpinia pulcherrima seeds.
\end{abstract}

Keywords: Caesalpinia pulcherrima, flamboyant mirim, forest seed, longevity, numbness

\section{Introduction}

The lack of information about seeds germination and physiological quality has been one of the main factors responsible for the inadequate formation of forest species seedlings, resulting in negative impacts in the establishment and uniformization of populations (Gasparin et al., 2013). This is due to the use of seeds of unknown quality, without any information about their germinative capacity and establishment potential.

Some species have survival mechanisms, such as seed dormancy, which results in a long time for germination. Moreover, the lack of certain information has resulted both in high costs in reforestation projects in degraded areas and in the substitution by species with lower potential (Araújo Neto et al., 2002). Seed storage is also an important factor in germination, helping to understand the propagation and consequent conservation of species (Marchiori, 2015).

The Caesalpinia pulcherrima (L.) (SW) forest species, known as marvel, is a woody shrub, originated in Central America, commonly found in all northeastern states of Brazil. The species has tolerance to heat and drought (Gilman \& Watson, 2003). It belongs to the Fabaceae family, and it is commonly used in afforestation and living fence because of its small size and inflorescence diversity. In addition to having medicinal properties, its parts are used for febrile, infections, mouth ulcers, wounds and eye irritation treatments (Gilman \& Watson, 2003).

Species from the Fabaceae family are known to present integumentary dormancy. However, studies conducted 
by Gilman and Watson (2003), Oliveira et al. (2010), Araújo Neto (2014), Naverrete-Tindall (2002), and Belinni et al. (2011) have shown variation in the C. pulcherrima species dormancy intensity. In the face of the need of information in order to optimize this species germination process, it is essential to know its behavior against environmental conditions, which can be determinant for its success in degraded areas environments.

Among the determinant environmental conditions, temperature, light, and substrate humidity are listed, which are the determinants in the germination process. In this sense, to explore the germinative capacity, before these factors, provides knowledge of information, which allows the use and maintenance of forest species, as temperature affects the germination capacity of seeds and the rate at which it occurs. Thus, it is extremely important to know the temperature limits in which a species can germinate, these limits being known by the cardinal temperatures (maximum, minimum and optimal) (Marcos Filho, 2015).

Light is one of the external factors that affect the growth and development of plants in different ways, from germination to dormancy overcoming. The analysis of the influence of light intensity contributes to the knowledge and classification of the species as for its photoblastism, so it is possible to analyze if the species has properties to germinate from the forest edge at full sun to its inside (Rossatto \& Kolb, 2010).

Besides the knowledge of germination conditioning factors, the evaluation of the seeds physiological quality is of fundamental importance for the knowledge of their physical and physiological attributes. In this sense, one of the tests that can be used to provide faster results is the tetrazolium test, which allows the observation of the staining of living tissues, indicating the seed viability (Oliveira, 2016).

Thus, the objective of this study was to evaluate the germination capacity of Caesalpinia pulcherrima species seeds under temperatures, pre-germination treatments, storage, water quantity in the substrate and verification of seed viability.

\section{Material and Methods}

\subsection{Place of Conducting Work}

The tests were carried out at the Plant Propagation Laboratory, at the Agricultural Sciences Center (CECA), Federal University of Alagoas, in the municipality of Rio Largo-AL $\left(09^{\circ} 28^{\prime} \mathrm{S}, 35^{\circ} 49^{\prime} \mathrm{W}\right.$ and $\left.127 \mathrm{~m}\right)$, and at the Plant Physiology Laboratory, Arapiraca Campus, at the same University, in Arapiraca-AL $\left(09^{\circ} 42^{\prime} \mathrm{S}, 36^{\circ} 41^{\prime} \mathrm{W}\right.$ and 264 m altitude).

The seeds were harvested from Caesalpinia pulcherrima plants located in the Arapiraca region $\left(09^{\circ} 74^{\prime} \mathrm{S}\right.$, $36^{\circ} 65^{\prime} \mathrm{W}, 260 \mathrm{~m}$ altitude). At the laboratory, the newly harvested seeds were taken to a forced circulation oven to determine the initial water content using the methodology described by the Rules for Seed Analysis (Brasil, 2009). After this stage, the seeds were stored in a dry chamber at $22{ }^{\circ} \mathrm{C}$, with $60 \%$ relative humidity until the beginning of the tests.

\subsection{Pre-germinative Treatments}

For the beginning of the tests, all the seeds were subjected to asepsis, with the immersion of the seeds in alcohol $(70 \%)$ (Rocha et al., 2008) for one minute, then washed with distilled water.

In the first test, two seed batches were used: one batch composed of newly harvested seeds and the other composed of seeds stored for one year in a regulated dry chamber $\left(22{ }^{\circ} \mathrm{C}\right.$ and $\left.60 \% \mathrm{UR}\right)$. These seeds were subjected to pre-germination treatments: intact seeds (control) and mechanical scarification with the use of number 80 sandpaper in the region opposite the hilum (Oliveira et al., 2010). The seeds were placed in plastic boxes $(1 \times 11 \times 3.5 \mathrm{~cm})$ followed by soaking, with twice the weight of the dry substrate, according to the Seed Analysis Rules (Brasil, 2009), and placed in germination chambers under temperatures of 30 and $20-30{ }^{\circ} \mathrm{C}$.

The germination evaluation was performed daily, being considered as germinated the seeds that presented primary root with $2 \mathrm{~mm}$ in length (Carreira \& Zaidan, 2007). At the end of the test, which lasted 15 days, the percentage of germination and germination velocity index (IVG) was determined by the sum of the number of seeds with primary root protrusion (G1, G2, G3,... Gn) each day, divided by the number of days elapsed (N1, N2, $\mathrm{N} 3$... Nn) between sowing and germination, according to the formula described by Maguire (1962):

$$
\mathrm{IVG}=\mathrm{G} 1 / \mathrm{N} 1+\mathrm{G} 2 / \mathrm{N} 2+\mathrm{G} 3 / \mathrm{N} 3+\ldots+\mathrm{Gn} / \mathrm{Nn}
$$

The Germina Quant 1.0 software (Marques et al., 2015) was used in this test to obtain the synchrony and uncertainty variables (Laboriau \& Valadares, 1976).

The results for the relative frequency (Fr) were determined according to Labouriau and Valadares (1976).

For the statistical analysis, a completely randomized design was used in a factorial scheme $(2 \times 2 \times 3)$ (two 
temperatures, two pre-germination treatments, three storage periods: freshly harvested seeds with six and 12 months of storage). The Sisvar software was used to obtain the variables.

\subsection{Light Quality}

In the second experiment, the physiological behavior of the seeds was verified according to temperature, light quality, and storage periods. For this, the seeds were placed in plastic boxes, then soaked with 2.5 -fold the weight of the dry substrate (Brasil, 2009) and incubated at temperatures of $30{ }^{\circ} \mathrm{C}$ and alternated at $20-30{ }^{\circ} \mathrm{C}$ under white LED light $(5,000 / 10000 \mathrm{~K})$ red $(630 \mathrm{~nm})$, far-red $(670 / 730 \mathrm{~nm})$ and dark. The dark condition was obtained by the use of gerbox painted with black paint. For treatments in wavelengths at red, far-red bands and absence of light, the asepsis, sowing and daily germination evaluation procedures were performed in a dark camera under a safety green light.

The design was completely randomized in a factorial scheme $(4 \times 2 \times 2)$ (white, red, extreme red light, the absence of light, two temperatures, and two storages) with four replicates of 25 seeds. The results were subjected to analysis of variance, and the averages were compared by the Tukey test at $5 \%$ probability.

\subsection{Substrate Water Volume}

In the third experiment, seed germination and the germination speed index were analyzed according to the water content to be made available on the germination substrate, that is, newly harvested seeds were placed on the substrate germitest paper moistened with amounts of water equivalent to $1.5,2.0,2.5,3.0$ and 3.5-fold the dry paper weight and kept in germination chambers at temperatures of 30 and $20-30{ }^{\circ} \mathrm{C}$ (Amaro, 2014).

In this experiment, the trial design was a completely randomized design, in a $5 \times 2$ factorial scheme (five water volumes and two temperatures), using four replicates of 25 seeds per treatment. The effects of the water volumes were studied by regression analysis, choosing the appropriate models to represent them according to their biological behavior, the coefficients significance, the model and the value of the determination coefficient $\left(\mathrm{R}^{2}\right)$ and the effects of temperature were studied by the Tukey test at $5 \%$ significance.

\subsection{Tetrazolium Test}

For the tetrazolium test, the Caesalpinia pulcherrima seeds were placed in plastic boxes, followed by soaking and placed in germination chambers under the temperature of $30{ }^{\circ} \mathrm{C}$ for 48 hours. Then, with the aid of a scalpel, longitudinal sections were cut in the seeds, obtaining the endosperm portion containing the embryo which was immersed in plastic cups containing $50 \mathrm{ml}$ of a triphenyl tetrazolium chloride solution of 2, 3, 5 at four concentrations of $0.075,0.1,0.5$ and $1.0 \%$, for three staining periods $\left(2,4\right.$ and 6 hours) in a chamber set at $30{ }^{\circ} \mathrm{C}$ in the dark. Four replicates of 25 seeds were used for each concentration, according to Oliveira (2016), with modifications.

\section{Results}

\subsection{Pre-germinative Treatments}

The interaction between the pre-germination treatments, storage and temperatures were statistically significant for the germination percentage (Table 1).

Table 1. Percentage of seed germination of Caesalpinia pulcherrima, submitted to two temperature regimes, storage and pre-germination treatments.

\begin{tabular}{|c|c|c|c|c|c|c|}
\hline \multirow{4}{*}{ Pre-germinative Treatments } & \multicolumn{6}{|c|}{ Storage (months) } \\
\hline & \multicolumn{2}{|c|}{0} & \multicolumn{2}{|c|}{6} & \multicolumn{2}{|r|}{12} \\
\hline & \multicolumn{6}{|c|}{ Temperature ${ }^{\circ} \mathrm{C}$} \\
\hline & 30 & $20-30$ & 30 & $20-30$ & 30 & $20-30$ \\
\hline Scarified & $91 \mathrm{aAa}$ & $89 \mathrm{aAa}$ & $42 \mathrm{aBa}$ & $31 \mathrm{aBa}$ & $85 \mathrm{aAa}$ & $88 \mathrm{aAa}$ \\
\hline Intact & $89 \mathrm{aAa}$ & $80 \mathrm{aAa}$ & $1.0 \mathrm{bBb}$ & $20 \mathrm{aBb}$ & $76 \mathrm{aAb}$ & $90 \mathrm{aAa}$ \\
\hline Value of " $F$ " for interaction $(\mathrm{A} \times \mathrm{G} \times \mathrm{T})$ & $3.883^{*}$ & & & & & \\
\hline $\mathrm{CV}(\%)$ & 15.00 & & & & & \\
\hline
\end{tabular}

Note. Surgery the same lowercase letter (for pre-germinative treatments and temperature) in the line and uppercase in the column (to storage) is not stand by the boat of Tukey, $5 \%$ probability.

* Significant by Tukey test at 5\% probability. 


\subsection{Pre-germinative Treatments IVG}

There was a significant interaction between factors, temperature, pre-germination treatments, and storage for the seed germination rate index (Table 2).

Table 2. Rate of germination rate of Caesalpinia pulcherrima submitted to two temperatures, storage and pre-germination treatments

\begin{tabular}{|c|c|c|c|c|c|c|}
\hline \multirow{4}{*}{ Pre-germination Treatments } & \multicolumn{6}{|c|}{ Storage (months) } \\
\hline & \multicolumn{2}{|c|}{0} & \multicolumn{2}{|c|}{6} & \multicolumn{2}{|c|}{12} \\
\hline & \multicolumn{6}{|c|}{ Temperature ${ }^{\circ} \mathrm{C}$} \\
\hline & 30 & $20-30$ & 30 & $20-30$ & 30 & $20-30$ \\
\hline Scarified & $1.21 \mathrm{bBb}$ & $1.51 \mathrm{bBb}$ & $1.49 \mathrm{bBb}$ & $1.31 \mathrm{bBb}$ & $1.50 \mathrm{bBb}$ & $1.42 \mathrm{bBb}$ \\
\hline Intact & $1.39 \mathrm{bBb}$ & $1.57 \mathrm{bBb}$ & $0.79 \mathrm{aAa}$ & $1.30 \mathrm{bBb}$ & $1.19 \mathrm{aBb}$ & $1.43 \mathrm{bBb}$ \\
\hline Value of " $F$ " for interaction $(\mathrm{A} \times \mathrm{Q} \times \mathrm{T})$ & $6.549 *$ & & & & & \\
\hline $\mathrm{CV}(\%)$ & 13.08 & & & & & \\
\hline
\end{tabular}

Note. $*$ Significant by the Tukey test at $5 \%$ probability.

Means followed by the same lower-case letter in the row (for pre-germination treatments and temperature) and upper case (for storage) in the column do not differ by Tukey test at 5\% probability.

\subsection{Pre-germinative Treatments Uncertainty of Germination}

The interaction between storage temperature and pre-germination treatments had an influence on the $C$. pulcherrima germination synchronicity and uncertainty, as a consequence of the conditions imposed on the

seeds germination. Asynchronicity was recorded when the germination of the intact seeds and the seeds with scarification were analyzed (Table 3 ).

Table 3. Uncertainty of germination of Caesalpinia pulcherrima seeds submitted to two temperatures, storage and pre-germination treatments

\begin{tabular}{|c|c|c|c|c|c|c|}
\hline \multirow{4}{*}{ Pre-germinative Treatments } & \multicolumn{6}{|c|}{ Storage (months) } \\
\hline & \multicolumn{2}{|c|}{0} & \multicolumn{2}{|c|}{6} & \multicolumn{2}{|c|}{12} \\
\hline & \multicolumn{6}{|c|}{ Temperature ${ }^{\circ} \mathrm{C}$} \\
\hline & 30 & $20-30$ & 30 & $20-30$ & 30 & $20-30$ \\
\hline Scarified & $2.58 \mathrm{aAa}$ & $2.11 \mathrm{aAb}$ & $1.56 \mathrm{aBa}$ & $1.31 \mathrm{aBa}$ & $2.22 \mathrm{aAa}$ & $2.05 \mathrm{aAa}$ \\
\hline Intact & $2.68 \mathrm{aAa}$ & $2.17 \mathrm{aAb}$ & $0.70 \mathrm{bCb}$ & $1.22 \mathrm{aBa}$ & $2.16 \mathrm{aAa}$ & $2.28 \mathrm{aAa}$ \\
\hline Value of " $\mathrm{F}$ " for interaction $(\mathrm{A} \times \mathrm{G} \times \mathrm{T})$ & $3.923^{*}$ & & & & & \\
\hline $\mathrm{CV}(\%)$ & 10.66 & & & & & \\
\hline
\end{tabular}

Note. * Significant by Tukey test at $5 \%$ probability.

Means followed by the same lowercase letter in the row (for pre-germinative treatments and temperature) and upper case in the column (for storage) do not differ from each other by the Tukey test at $5 \%$ probability.

\subsection{Pre-germinative Treatments Length of Caesalpinia Pulcherrima Seedlings}

Based on the seedlings total length values (Table 4), it was possible to identify that seeds with six months of storage presented smaller lengths when compared to six-month storage newly harvested seedlings. This decrease in the six-month storage intact seedling growth shows the induced dormancy that this storage time provided. In the scarified seeds, these lower averages can be explained by a small decrease in the germination percentage that occurred in this treatment, when compared to the others (Table 4). 
Table 4. Length of Caesalpinia pulcherrima seedlings, submitted to pre-germinating temperatures and storage

\begin{tabular}{lll}
\hline \multicolumn{3}{c}{ Storage (months) } \\
\hline 0 & 6 & 12 \\
\hline $1.309 \mathrm{a}$ & $0.836 \mathrm{~b}$ & $1.159 \mathrm{a}$ \\
\hline Value of "F" for storage (A) & $12.85^{*}$ & \\
$\mathrm{CV}(\%)$ & 24.46 & \\
\hline
\end{tabular}

Note. * Significant by Tukey test at 5\% probability .Means followed by the same lowercase letter in the row (for pre-germinative treatments and temperatures) and upper case in the column (for storage) do not differ from each other by the Tukey test at $5 \%$ probability.

\subsection{Pre-germinative Treatments Dry Mass of Caesalpinia Pulcherrima Seedlings}

The interaction between the factors was not significant in the total accumulation of the dry matter mass. However, storage influenced the values, showing higher averages in the newly harvested seeds and with twelve months of storage (Table 5), probably due to induced dormancy, which may have caused a delay in the seeds imbibition process and, consequently, the germination decreased.

Table 5. Dry mass of Caesalpinia pulcherrima seedlings, submitted to different storage conditions

\begin{tabular}{llc}
\hline \multirow{2}{*}{ Light Qualities } & \multicolumn{2}{c}{ Storage (months) } \\
\cline { 2 - 3 } & 0 & 12 \\
\hline White & $90.0 \mathrm{aA}$ & $86.5 \mathrm{aA}$ \\
Red & $98.0 \mathrm{aA}$ & $92.5 \mathrm{aA}$ \\
Extreme red & $98.0 \mathrm{aA}$ & $80.5 \mathrm{bA}$ \\
No light & $80 . \mathrm{aB}$ & $82.0 \mathrm{aA}$ \\
\hline Value of "F" $(\mathrm{A} \times$ luz $)$ & $3.410^{*}$ & \\
$\mathrm{CV}(\%)$ & 10.26 & \\
\hline
\end{tabular}

Note. * Significant by Tukey test at $5 \%$ probability.

Averages followed by the same lowercase letter in the row and upper case in the column do not differ from each other by the Tukey Test at 5\% probability.

\subsection{Light Quality}

The $C$. pulcherrima seeds showed a light-insensitive behavior, considering that the germinability occurred in all the photoblastic treatments evaluated, being considered neutral photoblastic (Table 6).

Table 6. Percentage of germination of Caesalpinia pulcherrima seeds, submitted to different light qualities, and storage

\begin{tabular}{|c|c|c|c|c|c|c|}
\hline \multirow{4}{*}{ Pre-germinative Treatments } & \multicolumn{6}{|c|}{ Storage (months) } \\
\hline & \multicolumn{2}{|c|}{0} & \multicolumn{2}{|c|}{6} & \multicolumn{2}{|c|}{12} \\
\hline & \multicolumn{6}{|c|}{ Temperature ${ }^{\circ} \mathrm{C}$} \\
\hline & 30 & $20-30$ & 30 & $20-30$ & 30 & $20-30$ \\
\hline Scarified & $9.71 \mathrm{aAa}$ & $9.69 \mathrm{aAa}$ & $8.90 \mathrm{aBa}$ & $7.33 \mathrm{aBb}$ & $10.57 \mathrm{aAa}$ & $10.43 \mathrm{aAa}$ \\
\hline Intac & $9.42 \mathrm{aAa}$ & $9.85 \mathrm{aAa}$ & $0.00 \mathrm{bBb}$ & $6.64 \mathrm{aBa}$ & $9.93 \mathrm{aAa}$ & $9.88 \mathrm{aAa}$ \\
\hline Value of " $\mathrm{F}$ " for interaction $(\mathrm{A} \times \mathrm{Q} \times \mathrm{T})$ & $6.549^{*}$ & & & & & \\
\hline CV (\%) & 13.08 & & & & & \\
\hline
\end{tabular}

Note. * Significant by Tukey test at 5\% probability.

Averages followed by the same lowercase letter in the row and upper case in the column do not differ from each other by the Tukey Test at 5\% probability. 


\subsection{IVG Quality of Light}

As for the germination speed index, the interaction between storage, temperature and light factors was not significant, only storage and light qualities had an influence on the Caesalpinia pulcherrima seeds IVG (Table 7).

Table 7. Rate of seed germination rate of Caesalpinia pulcherrima, submitted to different light qualities, storage types and temperature

\begin{tabular}{lll}
\hline \multirow{2}{*}{ Light Qualities } & \multicolumn{2}{c}{ Storage (months) } \\
\cline { 2 - 3 } & 0 & 12 \\
\hline White & $2.35 \mathrm{aA}$ & $2.14 \mathrm{bA}$ \\
Red & $1.22 \mathrm{bB}$ & $1.53 \mathrm{aB}$ \\
Extreme red & $1.22 \mathrm{aB}$ & $1.24 \mathrm{aC}$ \\
No light & $2.30 \mathrm{aA}$ & $2.28 \mathrm{aA}$ \\
\hline Value of "F"' (Storage $\times$ temperature) & 0.158 & \\
Value of "F" (Storage $\times$ light) & $5.763 *$ & \\
$\mathrm{CV}(\%)$ & 10.08 & \\
\hline
\end{tabular}

Note. ${ }^{*}$ Significant by Tukey test at $5 \%$ probability.

Averages followed by the same lowercase letter in the row and upper case in the column do not differ from each other by the Tukey Test at 5\% probability.

\subsection{Substrate Water Volume}

As for substrate moisture, it was verified that the interaction between water volume in the substrate and temperature influences the C. pulcherrima seeds germination (Figure 1A).

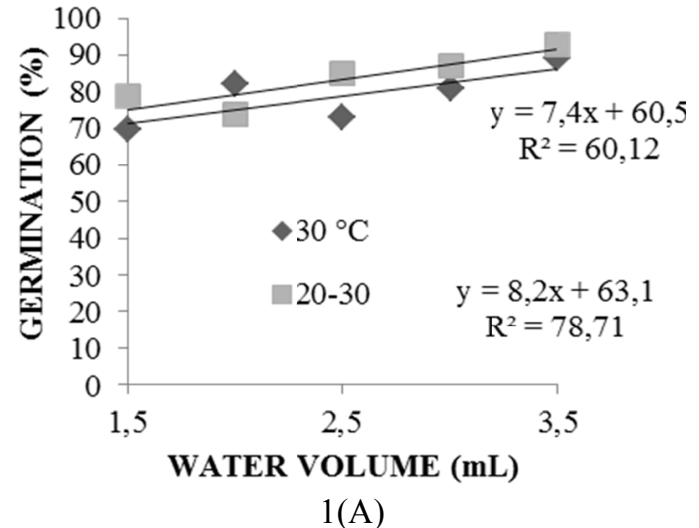

Figure 1(A). Percentage of germination of Caesalpiniapulcherrima submitted to five volumes of distilled water in the germination substrate and at two temperatures

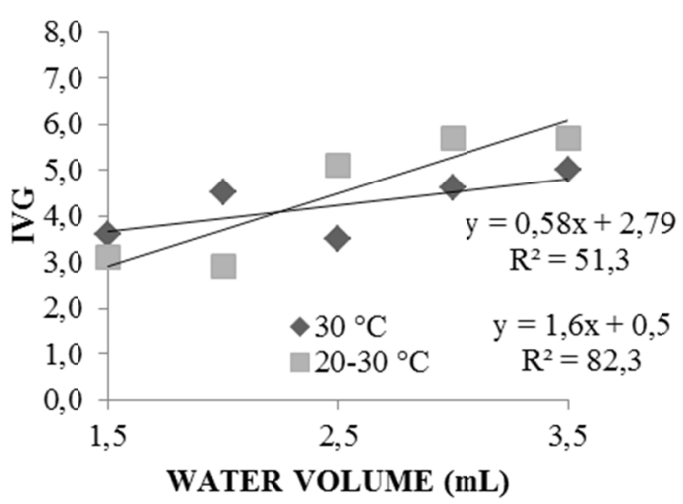

$1(B)$

Figure 1(B). Rate of seed germination rate of Caesalpinia pulcherrima submitted to water volumes and at two temperatures

\subsection{Tetrazolium Test}

The results for the percentage of viable seeds by the tetrazolium test at different concentrations, time of exposure and germination test, conducted at $30{ }^{\circ} \mathrm{C}$ in the C. pulcherrima seeds are shown in Table 8. It was observed that the interaction between the staining period and the concentrations of the tetrazolium salt solution were statistically significant. The concentrations of $0.075 \%$ (92\% of viable seeds) and $0.1 \%$ ( $91 \%$ of viable seeds) allowed to verify greater viability in the period of two and four hours of staining (Table 8), providing estimates similar to germination tests $(91 \%)$. 
Table 8. Viability of Caesalpinia pulcherrima seeds obtained by the germination test

\begin{tabular}{lllll}
\hline \multirow{2}{*}{ Coloring periods (hours) } & \multicolumn{4}{c}{ Concentrations of tetrazolium solution (\%) } \\
\cline { 2 - 5 } & 0.075 & 0.1 & 0.5 & 1.0 \\
\hline 2 & $92 \mathrm{aAz}$ & $91 \mathrm{aAz}$ & $11 \mathrm{bBy}$ & $10 \mathrm{bBy}$ \\
4 & $92 \mathrm{aAz}$ & $92 \mathrm{aAz}$ & $13 \mathrm{bAy}$ & $11 \mathrm{cAy}$ \\
6 & $23 \mathrm{bBy}$ & $54 \mathrm{aBy}$ & $0 \mathrm{cCy}$ & $0 \mathrm{cCy}$ \\
\hline & Germination $=91 \mathrm{z}$ & \\
\hline Value of "F" for periods $(\mathrm{P})$ & $418.00^{* *}$ & & \\
Value of "F" for concentrations (C) & $1347.22^{* *}$ & & \\
Value of "F" for interaction $(\mathrm{P} \times \mathrm{C})$ & $75.73^{* *}$ & & \\
Value of "F" for additional vs factorial & $702.76^{* *}$ & & \\
Value of "F" for treatments & $502.84^{* *}$ & & & \\
CV (\%) & 8.17 & & \\
\hline
\end{tabular}

Note. Means followed by the same uppercase letters (A, B, C) in the row and Lower case letters $(\mathrm{a}, \mathrm{b}, \mathrm{c})$ in the column do not differ significantly at $5 \%$ probability.

Means followed by the same letter $(\mathrm{z}, \mathrm{y})$ between germination (control-germination test) and viability obtained in the tetrazolium test did not differ significantly from the $5 \%$ probability by the Dunnett test.

\subsubsection{Tetrazolium Test}

The staining patterns were observed through the tetrazolium test in Caesalpinia $p$. seeds (Figure 2). The seeds that presented pink color throughout the length indicate viable seeds (Figures 2A, 2B and 2C), demonstrating the tissues vigor. However, seeds exposed to the tetrazolium solution showed intense red staining (Figure 2D), indicating tissue deterioration, while milk-white color (Figure 2E) showed non-viability (dead tissue).
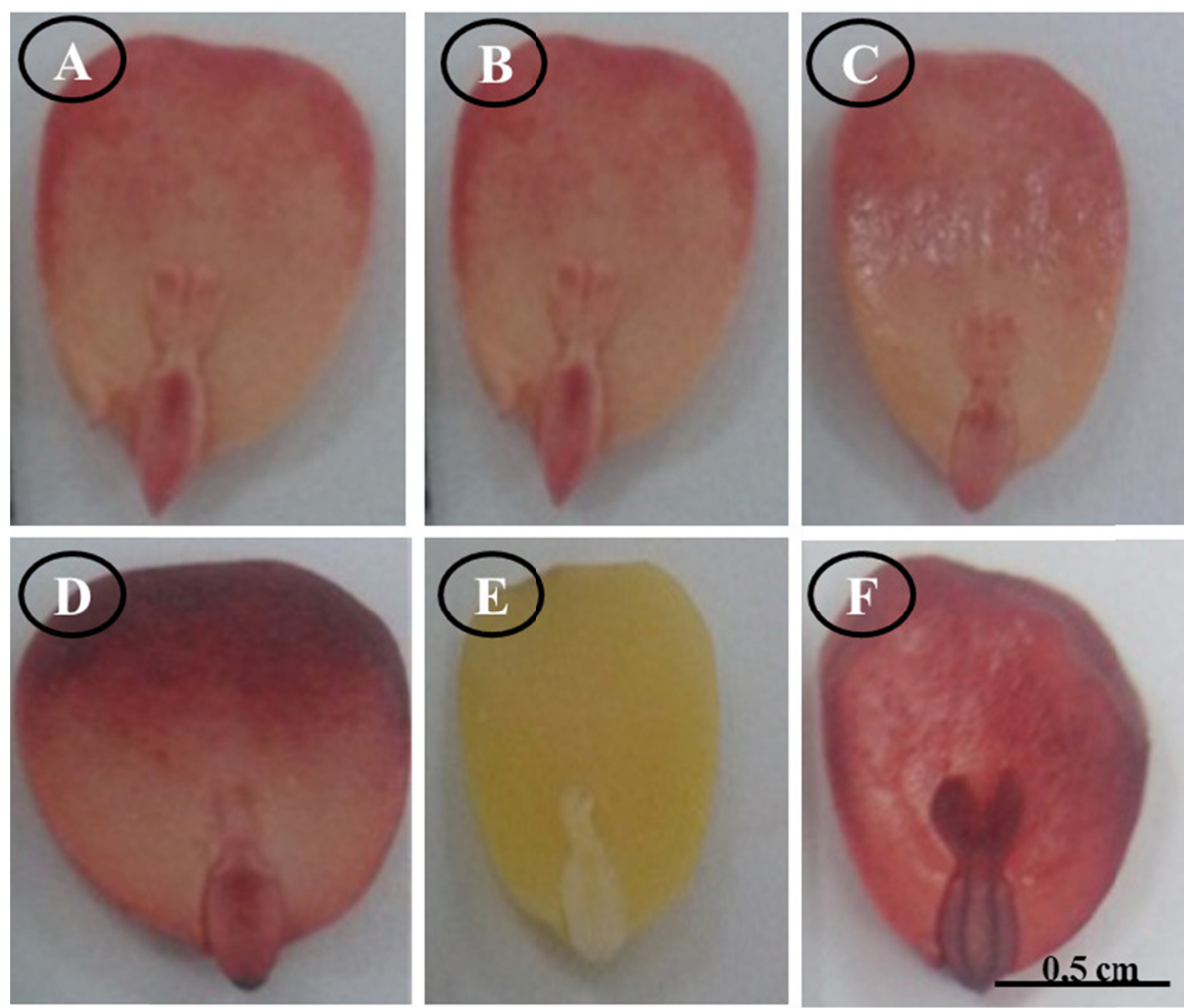

Figure 2. Viable seeds of Caesalpinia pulcherrima embryo with light pink color (A, B, C); hypocotyl-radicle seeds with intense red coloration in the cortex but not reaching the central cylinder (D). Inviable seeds: embryo with discolored/milky white areas (E); embryo with intense red color throughout its extension or hypocotyl-radicle axis with intense red color reaching the central cylinder $(\mathrm{F})$ 


\section{Discussion}

The Caesalpinia pulcherrima seeds presented a peculiar behavior, where the dormancy-breaking method did not influence the germination of the newly harvested seeds, that is, they did not present dormancy, having a germination percentage above $80 \%$ in the intact seeds (Table 1). However, seeds with six-month storage demonstrated an inhibition of the germinability potential with a percentage of $1 \%$ of germination at $30{ }^{\circ} \mathrm{C}$. This loss is surpassed by seeds with twelve-month storage, where the percentage increases again, reaching $90 \%$ of germination. This behavior can be related to a possible dormancy induced in the seeds with six months of storage, which is surpassed by the twelve-month storage.

This behavior can also be justified by the intensity dormancy variation among seeds of the same species.

It is believed that this difference in the Caesalpinia pulcherrima seed behavior may be related to the climatic conditions during the seed maturation stage, seed genetics, drying conditions, or environmental variations under which the seeds were collected (Guedes et al., 2015). Probably there are individual variations within the same species due to environmental influences during seed development and genetic variability (Turnbull, 1975; Santos et al., 2009).

The influence of the pre-germination treatments between intact seeds and those subjected to mechanical scarification at the alternating temperature of $20-30{ }^{\circ} \mathrm{C}$ (Table 1) in the three storages was not verified, which shows that the alternating temperatures resemble temperatures from the natural environment, and in this way, it can act as a dormancy-breaking method. According to Copeland and McDonald (1995), some species show better behavior in the germination process when subjected to temperature alternation.

Naverrete-Tindall (2002), and Belinni et al. (2011) mention that this species does not require pre-germination treatments and that intact, freshly harvested seeds reach 90 to $100 \%$ germination. However, studies by Gilman and Watson (2003), Oliveira et al. (2010) Araújo Neto (2014), Jozef et al. (2010), and Jayasuriya et al. (2013). found that the species presented dormancy and that the mechanical scarification method was efficient to overcome it, since the seeds subjected to this method had a higher germination percentage than those from the control treatment. This suggests that environmental conditions, in addition to storage conditions after the harvest period, may cause changes in their metabolism, since the seeds were collected in different regions as well as different climate, this being a sign for a possible response to a certain species behavior.

In the six-month storage period, the scarified seeds presented germination speed index higher than the intact seeds at $30^{\circ} \mathrm{C}$. At the alternating temperature $20-30^{\circ} \mathrm{C}$, there was no statistical difference between scarified and intact seeds regarding the germination speed (Table 2).

Data from this research show that the $30^{\circ} \mathrm{C}$ temperature, along with storage time, decreases the Caesalpinia pulcherrima seed germination rate, probably due to dormancy induction. However, the newly harvested seeds had higher IVG than seeds with six and twelve months of storage at $30^{\circ} \mathrm{C}$ (Table 2).

Results from Araújo Neto (2014) verified that the $30^{\circ} \mathrm{C}$ temperature provides higher IVG in the C. pulcherrima seeds when compared to the temperature of $25^{\circ} \mathrm{C}$. Oliveira et al. (2010) studying dormancy breaking methods in the same species, observed that the favorable condition for germination and IVG is under the temperature of $30^{\circ} \mathrm{C}$. Novembre et al. (1999) reported that Mimosa caesalpinia efolia seeds presented higher germination speed at $30^{\circ} \mathrm{C}$, and Fernández and Jimeénez (2014).

It is noted that intact seeds with six months of storage, under the temperature of $30^{\circ} \mathrm{C}$, indicate lower $\mathrm{U}$ values (Table 3). These values, however, did not induce greater synchrony of the germination process, under these conditions, but they can be related to the germination percentage, lower than other treatments.

In contrast, the alternating temperature $20-30$ and the temperature of $30{ }^{\circ} \mathrm{C}$ in freshly harvested seeds and seeds with 12 months of storage did not differ statistically, resulting in a unimodal behavior, which may suggest that these conditions may develop a physiological similarity in the seeds, causing uniformity in the germination. Dorneles, Ranal, and Santana (2013) declare that the lower asynchronicity in Anadenanthera colubrina germination and emergence values derive from the greater stability of thermal and humidity conditions of the germination environment.

Data from Rossatto and Kolb (2010) verified that lower temperatures caused loss of synchrony in the Pyrostegia venustae germination; greater synchrony in the optimal temperature between 30 and $35^{\circ} \mathrm{C}$. Melanoxylon braunna seeds showed higher synchronization in germination at temperatures of 25,30 and $35{ }^{\circ} \mathrm{C}$ (Flores et al., 2014). Therefore, the temperature is a determining factor in the germination process, which may affect germination uniformity (Carvalho \& Nakagawa, 2012). 
This decrease in the six-month storage intact seedling growth shows the induced dormancy that this storage time provided. In the scarified seeds, these lower averages can be explained by a small decrease in the germination percentage that occurred in this treatment, when compared to the others.

Guedes et al. (2015) verified significant differences in the Amburana cearenses seeds germination and seedling growth, collected during the same period and kept under the same storage conditions. J. R. O. Silva, Albuquerque, and I. C. O. Silva (2014) observed a decrease in Parkia pendula root growth with four months of storage.

These data corroborate with those of J. R. O. Silva, Albuquerque, and I. C. O. Silva (2014), where they verified that the Parkia pendula seeds showed an increase of the dry matter mass according to the storage time.

The inclusion of a seed in the classification of light sensitive/insensitive depends on the conditions of maturation, storage, imbibition and incubation temperature and osmotic treatment Ladeira et al. (1987), El-Keblawy et al. (2018). The occurrence of the germination process in all light qualities may be related to the capacity in which the C. pulcherrima seeds have to germinate from the forest edges at full sun to its inside, under the canopy (Rossatto \& Kolb, 2010). These data corroborate with data observed by Holanda et al. (Mimosa caesalpiniifolia Benth.), which germinated in any light environment, considered to be neutral photoblastic.

The influence of light on plant germination is mediated by phytochrome which corresponds to a class of photoreceptor pigments. These pigments' way of action depends on the means of incident radiation. The photosensitive seeds' germination derives from the active means of phytochrome that is caused by light with a high red/far-red ratio Takaki (2001), Benech-Arnold et al. (2000). Thus, seeds that present light insensitivity, such as the Caesalpinia pulcherrima species, must possess enough active means to induce germination in the absence of light, in the fiA way, which controls through a very low creep response (Menezes, 2004).

The temperature had no influence on germination in this experiment. The interaction between storage time and light quality was significant for germination, showing that the newly harvested seeds had a germination percentage (98\%) higher than seeds with twelve months of storage $(80.5 \%)$ under far-red light (Table 6). With these results, it can be considered that this light quality, along with storage time, influenced this species' the germination.

Although there was germination in all light qualities, it was observed that white, red and far-red light statistically provided higher results than the germination percentage found in the absence of light in the newly harvested seeds. However, this difference is non-existent in the seeds with 12 months of storage (Table 6). This may induce that the newly harvested seeds present a photodormency caused by the absence of light, which is overcome after storage.

In this sense, it can be considered that for the C. pulcherrima seeds the pre-existing phytochrome B no longer acts in the germination process during storage. There is, from this moment on, the action of type A phytochrome, which is, according to Takaki (2001), the type of phytochrome that acts on seeds of the neutral photoblastic type.

According to Marcos Filho (2015), the influence of light diminishes as the seeds age, revealing a natural alternative for survival, given that over time the deterioration phenomenon is irreversible and unavoidable.

Different from other studies on forest species, such as the Mimosa scabrella, Chorisias peciosa, Tabebuia avellanedae and Esenbeckia leiocarpa, where seed germination is higher in the dark, decreasing in the following order: red, blue, white and far-red light (Dias et al., 1992).

Data from Ferraz-Grande Takaki (2006) pointed out that Caesalpinia peltofhoroides seeds did not present photosensitivity, with no variation in the germinability percentage in the presence or absence of light, as well as in other photoblastic treatments.

In white light, the freshly harvested seeds had IVG superior to the seeds with 12 months of storage, demonstrating that the presence of white light and storage may reduce seed vigor.

Nogueira et al. (2014) observed that the Dalbergia cearensis seeds IVG showed no significant statistical difference between light and dark, stating that the Dalbergia cearensis seeds germination speed seems to be more influenced by temperature than by light quality.

The results were linearly presented, with the percentage above $70 \%$ in the volume of 1.5 -fold the dry substrate weight, showing linear growth with volume increase 2.0, 2.5, 3.0, reaching more than $90 \%$ in the volume of 3.5-fold the weight of the dry substrate. Vicente Noronha and Silberschmidt (1969) observed that the most favorable germination might not be induced only by one volume, but by several volumes, demonstrating the amplitude in the moistening range of the species. These results are in agreement with data from Ramos; Varela; 
and Melo (2006), who verified that the Ochroma pyramidale species had high germination index in all water volumes. In addition, it was necessary to add 3.0-fold the weight of dry substrate in order to obtain maximum germination (Amaro et al., 2014). Varela et al. (2005) studying the forest species from the Amazon states that the Angelim-stone (Dinizia excelsa) germination is not influenced by the amount of water in the substrate neither by the temperature.

The forest species Schizolobium amazonicum (paricá) presented better results in the volumes of 2.5 and 3.0-fold the dry substrate weight, with a percentage of $85 \%$ germination at $30{ }^{\circ} \mathrm{C}$ (Ramos, Varela, \& Melo, 2006).

In the results of the germination speed index (IVG) the interaction between temperature and water volumes was significant, presenting linear growth as the water volume increased (Figure 1B).

The temperature of $30^{\circ} \mathrm{C}$ provided higher seed germination speed in the volume of 1.5 -fold the substrate weight (Figure 1B). The volume of water was 3.5-fold the weight of the dried substrate, which allowed a better germination speed, both at $30{ }^{\circ} \mathrm{C}$ and $20-30{ }^{\circ} \mathrm{C}$. However, the volume of 1.5 -fold the dry paper weight at the alternating temperature shows lower IVG when compared to other volumes. Thus, volumes larger than 2.0-fold the substrate weight are indicated for germination tests of this species at alternate temperature.

The water volume did not influence the Ochroma pyramidale seed germination speed index, although, higher temperatures favored the process (Ramos, Varela, \& Melo, 2006).

Paricá seeds presented similar behavior with germination speed indexes of 5.3 and 5.8 in the volumes of 2.5 and 3.0, respectively, at $30{ }^{\circ} \mathrm{C}$ (Ramos, Varela, \& Melo, 2006). Varela et al. (2004) state that seed germination rate of $D$. excelsa was neither influenced by the water volumes in the substrate nor the temperatures.

Analyzing the relative frequency in different volumes of water in the substrate, it was observed that at $20-30{ }^{\circ} \mathrm{C}$ the germination has a unimodal character with germination peaks in the volumes of 1.5 and 2.0-fold the substrate weight. Nevertheless, in the volumes of $1.5,2.0,2.5,3.0$ and 3.5 at $30{ }^{\circ} \mathrm{C}$ the seeds germinated in a shorter time, as well as in the volumes of 2.5, 3.0 and 3.5 at alternating temperature, resulting in a polymodal distribution aspect (data not shown).

This way, the use of these concentrations in the two-hour period, at $30{ }^{\circ} \mathrm{C}$ is suggested for this species, for laboratory viability analyzes since it allows one to obtain results faster than germination tests. Studies with Fabaceae found that lower concentrations allow more appropriate viability results to be verified with germination tests than with higher tetrazolium salt concentrations, as it is with Pterodon pubescens (Ferreira et al., 2001), Senna multijuga and Senna macranthera seeds (Ferreira et al., 2004).

These results are consistent with Oliveira's (2016) claims that Simira gardneriana seeds present higher viability averages as concentrations increase, at temperatures of $30{ }^{\circ} \mathrm{C}$, but not in the two nor in the four-hour periods. The concentration of $0.075 \%$ in the period of two hours also allowed better results in brazilwood (Caesalpinia echinata Lam.) Seeds (Lamarca, Leduc, \&, Barbedo, 2009).

The main characteristic after seed exposure to tetrazolium solution is the difference in tissue staining, which allows interpreting test results (Oliveira et al., 2016). The color intensity of the seeds after the tetrazolium test varies among species. As well as in the exposure period, in forest seeds, there are variations to perform the tests and staining evaluations. For Erythrina velutina Willd seeds, 6 hours of imbibition with 3 hours of immersion at a concentration of $0.075 \%$ tetrazolium salt is the ideal time for conducting the tetrazolium test (Cunha \& Gomes, 2015).

Thus, the concentrations of $0.075 \%$ and $0.1 \%$ tetrazolium salt solution for 2 hours, at $30{ }^{\circ} \mathrm{C}$, are indicated to analyze the viability of Caesalpinia pulcherrima seeds in the tetrazolium test.

\section{Conclusions}

Mechanical scarification with sandpaper (No. 80) did not influence the germination of Caesalpinia pulcherrima.

C. pulcherra seeds are neutral photoblastic.

Moistening the substrate in water volumes of 3.5-fold the dry substrate weight gives better results for the species. Tetrazolium salt concentrations of $0.075 \%$ and $0.1 \%$ at $30{ }^{\circ} \mathrm{C}$ for 2 hours are efficient for seed viability analysis.

\section{Acknowledgements}

The authors wish to express their gratitude to Fundação de Amparo à Pesquisa no Estado de Alagoas-FAPEAL for the sholarship, to Centro Nacional de Desenvolvimento Científico e Tecnológico-CNPq and to Universidade Federal de Alagoas, campus Arapiraca for research support. 


\section{References}

Amaro, H. T. R., de Souza David, A. M. S., de Souza Cangussú, L. V., Rodrigues, B. R. A., de Oliveira Assis, M., \& Veloso, C. S. (2014). Umedecimento do substrato e temperatura na germinação e vigor de sementes de melão. Semina: Ciências Agrárias, 35(3), 1119-1130. https://doi.org/10.5433/1679-0359.2014v35 n3p1119

Araújo Neto, J. C. (2014). Caracterização morfométrica, germinação e conservação de sementes de Caesalpinia pulcherrima (L.) SW (Fabaceae: Caesalpinioidea). Semina: Ciências Agrárias, 35(4). https://doi.org/ 10.5433/1679-0359.2014v35n4Suplp2287

Araujo Neto, J. C., Aguiar, I. B., Ferreira, V. M., \& Rodrigues, T. de J. D. (2002).Temperaturas cardeais e efeito da luz na germinação de sementes de mutamba. Revista Brasileira de Engenharia Agrícola e Ambiental, 6, 460-465. https://doi.org/10.1590/S1415-43662002000300013

Belini, C. (2011). Escarificação em sementes e germinação de flamboyant mirim (Caesalpinia pulcherrima). Fórum de Meio Ambiente do Centro Universitário Unifafibe, 3, Bebedouro, SP. Resumos... Bebedouro, SP: UNIFAFIBE. Retrieved from http://unifafibe.com.br/revistasonline/arquivos/revistabiologia/sumario/15/ 18062011074633.pdf

Benech-Arnold, R. L., Sánchez, R. A., Forcella, F., Kruk, B. C., \& Ghersa, C. M. (2000). Environmental control of dormancy in weed seed banks in soil. Field Crops Research, 67(2), 105-122. https://doi.org/10.1016/ S0378-4290(00)00087-3

Bezerra Pereira, F. E. C., Porfírio Guimarães, I., Barros Torres, S., \& Pereira Benedito, C. (2015). Superação de dormência em sementes de Pithecellobium dulce (Roxb.) Benth. Semina: Ciências Agrárias, 36(1).

Borges, E. D. L., \& Rena, A. B. (1993). Germinação de sementes. Sementes florestais tropicais (pp. 83-136). Brasília: ABRATES.

Brasil. (2009). Regras para análise de sementes. Brasília: Mapa/ACS.

Cardoso, V. J. M. (2004). Germinação. In G. B. Kerbauy (Ed.), Fisiologia vegetal (Cap. 17, pp. 386-408). São Paulo: Guanabara koogan.

Carreira, R. C., \& Zaidan, L. B. P. (2007). Germinação de sementes de espécies de Melastomataceae de Cerrado sob condições controladas de luz e temperatura. Hoehnea, 34(3), 261-269. https://doi.org/10.1590/ S2236-89062007000300001

Carvalho, N. D., \& Nakagawa, J. (2000). Sementes: Ciência, tecnologia e produção (Vol. 4). Jaboticabal: Funep. https://doi.org/10.17801/0101-3122/rbs.v22n1p185-192

Copeland, L. O., \& McDonald, M. B. (1995). Principles of Seed Science and Technology (p. 181). Chapman and Hall. New York.

Cunha, M. C. L., \& Gomes, I. H. R. A. (2015). Viabilidade de sementes de Erythrina velutina willd pelo teste de tetrazólio. Nativa, 3(3), 196-200. https://doi.org/10.14583/2318-7670.v03n03a08

Dias-Filho, M. B. (1998). Alguns aspectos da ecologia de sementes de duas espécies de plantas invasoras da Amazônia brasileira: Implicações para o recrutamento de plântulas em áreas manejadas. Floresta amazônica: Dinâmica, regeneração e manejo (pp. 233-248). Manaus: INPA.

Dorneles, M. C., Ranal, M. A., \& de Santana, D. G. (2013). Germinação de sementes e emergência de plântulas de Anadenanthera colubrina (Vell.) Brenan var. cebil (Griseb.) Altschut, Fabaceae, estabelecida em fragmentos florestais do cerrado, MG. Ciência Florestal, 23(3), 291-304. https://doi.org/10.5902/ 1980509810541

El-Keblawy, A., Al-Shamsi, N., \& Mosa, K. (2018). Effect of maternal habitat, temperature and light on germination and salt tolerance of Suaeda vermiculata, a habitatindifferent halophyte of arid Arabian deserts. Seed Science Research, 28, 140-147. https:// doi.org/10.1017/S0960258518000144

Fernández, P., \& Jiménez, A. (2014). Phenotypic plasticity in seed germination relates differentially to overwintering and owering temperatures. Seed Science Research, 24, 273-280. https://doi.org/10.1017/ S0960258514000269

Ferraz-Grande, F. G., \& Takaki, M. (2001). Temperature dependent seed germination of Dalbergia nigra Allem (Leguminosae). Brazilian Archives of Biology and Technology, 44(4), 401-404. https://doi.org/10.1590/ S1516-89132001000400010 
Ferreira, R. A., Davide, A. C., \& Motta, M. S. (2004). Vigor e viabilidade de sementes de Senna multijuga (Rich.) Irwin et Barn. e Senna macranthera (Collad.) Irwin et Barn., num banco de sementes em solo de viveiro. Revista Brasileira de Sementes, 26(1), 24-31. https://doi.org/10.1590/S0101-31222004000100004

Ferreira, R. A., Vieira, M. G. G. C., Von Pinho, E. V. R., \& Tonetti, O. A. O. (2001). Morfologia da semente e de plântulas e avaliação da viabilidade da semente de sucupira-branca (Pterodon pubescens Benth.-Fabaceae) pelo teste de tetrazólio. Revista Brasileira de Sementes, 23(1), 108-115. https://doi.org/10.17801/01013122/rbs.v23n1p108-115

Gasparin, E., Araujo, M. M., Tolfo, C. V., Foltz, D. R. B., \& Magistrali, P. R. (2013). Substrates for germination and physiological quality of storage seeds of Parapiptadenia rigida (Benth.) Brenan. Journal of Seed Science, 35(1), 77-85. https://doi.org/10.1590/S2317-15372013000100011

Gilman, E. F., \& Watson, D. G. (2003). Caesalpinia pulcherrima Dwarf Poinciana. USDA Forest Service Fact Sheet ST-107 (p. 3). Retrieved from http://www.edis.ifas.ufl.edu/pdffiles/ST/ST10700.pdf

Guedes, R. S., Alves, E. U., Gonçalves, E. P., Braga Júnior, J. M., Viana, J. S., \& Colares, P. N. Q. (2010). Substratos e temperaturas para testes de germinação e vigor de sementes de Amburana cearensis (Allemão) AC Smith. Revista Árvore, 34(1), 57-64. https://doi.org/10.1590/S0100-67622010000100007

Holanda, A.; Emanuel R., Medeiros, F., S., \& Diogo, I. J. S. (2015). Influência da luz e da temperatura na germinação de sementes de sabiá (Mimosa caesalpiniifolia Benth.-Fabaceae). Gaia Scientia, 9(1).

Jayasuriya, K. M. G., Asanga, S. T. B., Wijetunga, J. M. B., \& Carol, C. B. (2013). Seed dormancy and storage behaviour in tropical Fabaceae: A study of 100 species from Sri Lanka. Seed Science Research, 23, 257-269. https://doi.org/10.1017/S0960258513000214

Jozef, A. Van A., \& Filip, E. A. V. (2010). Combinational dormancy in winter annual Fabaceae. Seed Science Research, 20, 237-242.

Labouriau, L. G. (1983). A germinação da semente. Washington: Secretaria Geral da O.E.A.

Labouriau, L. G., \& Valadares, M. E. B. (1976). On the germination of seeds of Calotropis procera (Ait.) Ait.f. Anais da Academia Brasileira de Ciências, 48, 263-284.

Ladeira, A. M., Guardia, M. C., \& Takaki, M. (1987). Manipulation of seede germination in Plantagoto mentosa Lant. and Rhapanus sativus. Seed Science andTecnology, 15, 55-63.

Lamarca, E. V., Leduc, S. N. M., \& Barbedo, C. J. (2009). Viabilidade e vigor de sementes de Caesalpinia echinata Lam.(pau-brasil-Leguminosae) pelo teste de tetrazólio. Revista Brasileira de Botânica, 32(4) 793-803. https://doi.org/10.1590/S0100-84042009000400017

Maguire, J. D. (1962). Speed of germination aid in selection and evaluation for seedling emergence and vigor. Crop Science, 2(2), 176-177. https://doi.org/10.2135/cropsci1962.0011183X000200020033x

Marchiori, N. M., Fidelis, A. T., Kozovits, A. R., \& Garcia, Q. D. S. (2015). Germinação de sementes nativas dos campos sulinos após armazenamento e choque de temperatura. Revista Biociências, 21(1) 89-99.

Marcos, F. J. (2015). Fisiologia de sementes de plantas cultivadas. Piracicaba: Fealq.

Marques, F. R. F. (2015). Germina Quant: A new tool for germination measurements. Journal of Seed Science, 37(3), 248-255. https://doi.org/10.1590/2317-1545v37n3145605

Menezes, N. D., Franzin, S. M., Roversi, T., \& Nunes, E. P. (2004). Germinação de sementes de Salvia splendens Sellow em diferentes temperaturas e qualidades de luz. Revista Brasileira de Sementes, 26(1), 32-37. https://doi.org/10.1590/S0101-31222004000100005

Novembre, A. D. L. C., \& Marcos Filho, J. (1999). Estudo da metodologia para condução do teste de germinação em sementes de algodão deslintadas mecanicamente. Revista Brasileira de Sementes, 21(2), 187-193. https://doi.org/10.17801/0101-3122/rbs.v21n2p187-193

Oliveira, F. N. D., Torres, S. B., Nogueira, N. W., \& Freitas, R. M. O. D. (2016). Viability of Simira gardneriana MR Barbosa \& Peixoto seeds by the tetrazolium test. Journal of Seed Science, 38(1), 7-13. https://doi.org/ $10.1590 / 2317-1545 \mathrm{v} 38 \mathrm{n} 1153565$

Oliveira, L. M., Bruno, R. D. L. A., Gonçalves, E. P., \& de Lima Júnior, A. R. (2010). Tratamentos pré-germinativos em sementes de Caesalpinia pulcherrima (L.) SW.-Leguminosae. Revista Caatinga, 23(1), 71-76. 
Ramos, M. B. P., Varela, V. P., \& Melo, M. D. F. F. (2006). Influência da temperatura e da quantidade de água no substrato sobre a germinação de sementes de Ochroma pyramidale (Cav. ex Lam.) Urban (pau-de-balsa). Acta Amazônica, 36(1), 103-106. https://doi.org/10.1590/S0044-59672006000100012

Rocha, M. (2008). Enraizamento in vitro e aclimatização de genótipos de jenipapeiro (Genipa americana L.). Revista Brasileira de Fruticultura, 30(3), 769-774. https://doi.org/10.1590/S0100-29452008000300035

Rossato, D., \& Kolb, R. (2010). Germinação de Pyrostegia venusta (Bignoniaceae), viabilidade de sementes e desenvolvimento pós-seminal. Revista Brasil. Bot., 33(1), 51-60. https://doi.org/10.1590/S0100-84042010 000100006

Santos, F. S., Paula, R. C., Sabonaro, D. Z., \& Valadares, J. (2009). Biometria e qualidade fisiológica de sementes de diferentes matrizes de Tabebuia chrysotricha (Mart. ex A. DC.) Standl. Scientia Forestalis, Piracicaba, 37(82), 163-173.

Silva, F. J. D., Hisatugo, E. Y., \& Souza, J. P. D. (2016). Light effects on germination and early development of physic nut (Jatropha curcas L.) from distinct geographical provenances. Hoehnea, 43(2), 195-202. https://doi.org/10.1590/2236-8906-80/2015

Silva, J. R. O., Albuquerque, M. C. F., \& Silva, I. C. O. (2014). Storage of Parkia pendula (Willd.) Benth.ex Walp (Fabaceae) seeds in different types of packaging and environments. Floresta e Ambiente, 21(4), 457-467. https://doi.org/10.1590/2179-8087.054013

Takaki, M. (2001). New proposal of classification of seed based on forms of phytochrome instead of photoblastism. Revista Brasileira de Fisiologia Vegetal, 13, 103-107. https://doi.org/10.1590/S010331312001000100011

Turnbull, J. W. (1975). Seed extraction and cleaning. REPORT on the FAO/DANIDA training course on forest seed collection and handling. Rome: FAO.

Varela, V. P.; Ramos, M. B. P., Melo, M. F. F. (2005). Umedecimento do substrato e temperatura na germinação de sementes de angelim-pedra (Dinizia excelsa Ducke). Revista Brasileira de Sementes, 27(2), 130-135. https://doi.org/10.1590/S0101-31222005000200019

Vasconcelos Flores, A., Euclydes de Lima e Borges, E., Monteze Guimarães, V., de Carvalho Gonçalves, J. F., da Mata Ataíde, G., \& de Pádua Barros, D. (2014). Atividade enzimática durante a germinação de sementes de Melanoxylon brauna Schott sob diferentes temperaturas. Cerne, 20(3). https://doi.org/10.1590/010477 60201420031399

Walessa Nogueira, N., Barros Torres, S., \& Oliveira de Freitas, R. M. (2014). Teste de tetrazólio em sementes de timbaúba. Semina: Ciências Agrárias, 35(6).

\section{Copyrights}

Copyright for this article is retained by the author(s), with first publication rights granted to the journal.

This is an open-access article distributed under the terms and conditions of the Creative Commons Attribution license (http://creativecommons.org/licenses/by/4.0/). 